\title{
Vapor Phase Decarbonylation of Furfural to Furan over Nickel Supported on SBA-15 Silica Catalysts
}

\author{
Diana Vargas-Hernández ${ }^{1 *}$, Juan Miguel Rubio-Caballero², Ramon Moreno-Tost², \\ Josefa María Mérida-Robles², José Santamaría-González², Antonio Jiménez-López ${ }^{2}$, \\ María Ana Pérez-Cruz ${ }^{3}$, Rosario Hernández-Huesca ${ }^{3}$, Pedro Maireles-Torres ${ }^{2}$ \\ ${ }^{1}$ Catedrática CONACYT-Universidad de Sonora, Hermosillo, México \\ ${ }^{2}$ Departamento de Química Inorgánica, Cristalografía y Minerología (Unidad Asociada al ICP-CSIC), Facultad de \\ Ciencias, Universidad de Málaga, Málaga, Spain \\ ${ }^{3}$ Facultad de Ciencias Químicas, Benemérita Universidad Autónoma de Puebla, Puebla, México \\ Email: *dvargashe@conacyt.mx
}

Received 19 April 2016; accepted 12 July 2016; published 15 July 2016

Copyright (C) 2016 by authors and Scientific Research Publishing Inc.

This work is licensed under the Creative Commons Attribution International License (CC BY). http://creativecommons.org/licenses/by/4.0/

(c) (i) Open Access

\begin{abstract}
Vapor-phase transformations of furfural over SBA-15 silica supported Ni catalysts under $\mathrm{H}_{2}$ in a continuous-flow reactor at atmospheric pressure and $170^{\circ} \mathrm{C}$ and $230^{\circ} \mathrm{C}$ were investigated. Two different samples having Ni loadings of 5 and $20 \mathrm{wt} \%$ (denoted here by SBA-5Ni and SBA-20Ni, respectively) were prepared by impregnation and characterized by atomic absorption spectroscopy, $\mathrm{N}_{2}$ sorption analysis, X-ray diffraction, X-ray photoelectron spectroscopy, and transmission electron microscopy. Furan and furfuryl alcohol were two primary products resulting, respectively, from decarbonylation and hydrogenation of furfural. Under the conditions of the study, both reactions exhibited structure sensitivity evidenced by changes in product selectivities with variable Ni loadings. Compared with SBA-20Ni, the $5 \mathrm{wt} \% \mathrm{Ni}$ catalyst showed better catalytic activity, reaching a furfural conversion of $100 \mathrm{~mol} \%$ and a selectivity to furan of $98 \mathrm{~mol} \%$, after $5 \mathrm{~h}$ of timeon-stream at $230^{\circ} \mathrm{C}$.
\end{abstract}

\section{Keywords}

Ni-SBA-15, Furfural, Hydrogenation, Furan, Furfuryl Alcohol

\footnotetext{
${ }^{*}$ Corresponding author.

How to cite this paper: Vargas-Hernández, D., Rubio-Caballero, J.M., Moreno-Tost, R., Mérida-Robles, J.M., SantamaríaGonzález, J., Jiménez-López, A., Pérez-Cruz, M.A., Hernández-Huesca, R. and Maireles-Torres, P. (2016) Vapor Phase Decarbonylation of Furfural to Furan over Nickel Supported on SBA-15 Silica Catalysts. Modern Research in Catalysis, 5, 85-94. http://dx.doi.org/10.4236/mrc.2016.53008
} 


\section{Introduction}

Lignocellulosic biomass has attracted significant attention worldwide as a feedstock for renewable liquid fuels and chemical production due to its low cost and availability. The acid-catalyzed dehydration of pentoses and hexoses derived from renewable biomass resources can produce furan derivatives, such as furfural (FA) and 5-hydroxymethylfurfura. Furfural is a major product and a rich source of derivatives that are potential biofuel components [1]-[3]. These include furan, furfuryl alcohol, 2-methylfuran, and tetrahydrofurfuryl alcohol, which can be obtained by furfural decarbonylation or hydrogenation reactions, either in liquid or gas phase. The main products of furfural arise from the hydrogenation of the $\mathrm{C}=\mathrm{O}$ bond and/or the furan ring. Depending on the application of metal catalysts for the hydrogenation of furfural or its primary products, decarbonylation [4] and hydrogenolysis of the etheric C-O single bond can also proceed [5]. Due to the wide variety of hydrogenation products of furfural, it is still attractive to design catalysts that are highly selective to the desired products. Different transition metals show different catalytic activity with respect to transformations of the highly reactive carbonyl group of furfural. For instance, $\mathrm{Cu}$ is highly selective for hydrogenation of furfural to furfuryl alcohol [6]-[10]; Pd is an efficient catalyst for decarbonylation of furfural to furan [7] [11]-[14]; and Ni and Pt, depending on conditions, can promote both reactions to different extents [7] [15] [16]. At lower temperatures, the hydrogenation activity becomes significant, which leads to the formation of furfuryl alcohol, while at high temperatures $\left(230^{\circ} \mathrm{C}\right)$ the decarbonylation reaction dominates to produce furan. These primary products are further converted in secondary reactions. Furan yields $\mathrm{C}_{4}$ products (butanal, butanol, and butane) via ring opening, while furfuryl alcohol produces 2-methylfuran via C-O hydrogenolysis [15].

Furan and related compounds are useful starting materials for the industrial production of chemicals used as pharmaceuticals, herbicides, stabilizers, and polymers. For example, furan is used to make tetrahydrofuran, polytetramethylene glycol, polyether ester elastomers, and polyurethane elastomers.

Therefore, one of the goals of this study was to find a catalyst that was able to produce furan while suppressing the formation of alcohol furfuryl. In the present work, we have investigated the conversion of furfural over $\mathrm{Ni}$ catalysts. The effect of loading $\mathrm{Ni}$ on the catalytic properties of silica-supported $\mathrm{Ni}$ is investigated. Samples with different Ni loading were prepared and characterized by XRD, TEM, TPR, XPS, and the BET method to evaluate the structural changes and the extent of alloy formation.

\section{Experimental}

\subsection{Catalysts Synthesis and Characterization}

The synthesis of SBA-15 silica was carried out as reported by Zhao et al. [17]. The SBA-Ni catalysts were prepared by impregnation with aqueous solutions of $\mathrm{Ni}\left(\mathrm{NO}_{3}\right)_{2} \cdot 6 \mathrm{H}_{2} \mathrm{O}$ (Aldrich, $>99 \%$ purity). After impregnation, the catalysts were dried for $12 \mathrm{~h}$ at room temperature, and, after that, calcined for $6 \mathrm{~h}$, at $400^{\circ} \mathrm{C}$, with a heating rate of $1^{\circ} \mathrm{C} / \mathrm{min}$. The metal loadings were 5 and $20 \mathrm{wt} \%$ of Ni. The catalysts were labeled as SBA-xNi, where $\mathrm{x}$ is the $\mathrm{wt} \%$ of $\mathrm{Ni}$.

Nickel content was determined by atomic adsorption spectroscopy (AAS) using a Varian SpectrAA 50 spectrometer. Elemental analysis was performed on a PERKIN-ELMER $2400 \mathrm{CHN}$ with a LECO VTF900 pyrolysis oven.

$\mathrm{N}_{2}$ adsorption-desorption isotherms of the calcined catalysts at $77 \mathrm{~K}$ were obtained using a Micromeritics ASAP 2020 gas adsorption analyzer. Prior to $\mathrm{N}_{2}$ adsorption, the samples were evacuated overnight at $200^{\circ} \mathrm{C}$ and $1 \times 10^{-2} \mathrm{~Pa}$. Pore size distributions were calculated by the BJH method [18].

Powder X-ray diffraction (XRD) patterns were obtained by using a Siemens D5000 automated diffractometer in the Bragg-Brentano geometry with $\mathrm{Cu} \mathrm{K} \alpha$ radiation and a graphite monochromator.

The reducibility of the calcined samples was determined by $\mathrm{H}_{2}$ temperature-programmed reduction $\left(\mathrm{H}_{2}-\mathrm{TPR}\right)$. For these measurements, $80 \mathrm{mg}$ of sample was placed in a quartz reactor and heated up to $100^{\circ} \mathrm{C}$, under a He flow of $35 \mathrm{ml} / \mathrm{min}$, and held at this temperature for $1 \mathrm{~h}$. The reactor was then cooled down to $50^{\circ} \mathrm{C}$ and the sample exposed to a $\mathrm{H}_{2} / \mathrm{Ar}$ stream of $47 \mathrm{ml} / \mathrm{min}$. Subsequently, the sample was heated up to $700^{\circ} \mathrm{C}$ at a heating rate of $10^{\circ} \mathrm{C} / \mathrm{min}$. The amount of hydrogen consumed as a function of temperature was monitored on-line by a TCD detector. The water formed during reduction was collected with a cryogenic trap at $-85^{\circ} \mathrm{C}$ before chromatographic analysis. 
X-ray photoelectron spectroscopy studies were performed with a Physical Electronics PHI 5700 spectrometer equipped with a hemispherical electron analyzer (model 80-365B) and a $\mathrm{Mg} \mathrm{K} \alpha$ (1253.6 eV) X-ray source. High-resolution spectra were recorded at a $45^{\circ}$ take-off-angle by a concentric hemispherical analyzer operating in the constant pass energy mode at $29.35 \mathrm{eV}$, using a $720 \mu \mathrm{m}$ diameter analysis area. Charge referencing was done against adventitious carbon (C $1 \mathrm{~s}$ at $284.8 \mathrm{eV}$ ). The pressure in the analysis chamber was kept lower than $5 \times$ $10^{-6} \mathrm{~Pa}$. The PHI ACCESS ESCA-V6.0 F software package was used for data acquisition and analysis. A Shirley-type background was subtracted from the signals. Recorded spectra were always fitted using Gauss-Lorentz curves in order to determine more accurately the binding energy of the different element core levels. The samples underwent the same aforementioned ex situ treatment before XPS analysis.

The morphology of the catalysts was evaluated by transmission electron microscopy (TEM). Before TEM analysis, the samples were reduced ex situ under pure $\mathrm{H}_{2}(60 \mathrm{ml} / \mathrm{min})$ at $450^{\circ} \mathrm{C}$ for $2 \mathrm{~h}$, and stored in cyclohexane (Sigma-Aldrich, 99\% purity).

\subsection{Catalytic Activity Testing}

The vapor-phase reaction of furfural was conducted in a 1/4" tubular quartz reactor. The pelletized catalyst (325 $400 \mu \mathrm{m}$ ) was placed at the center of the reactor tube between two layers of glass beads and quartz wool. The catalysts were reduced in situ, under a $\mathrm{H}_{2}$ flow $(60 \mathrm{ml} / \mathrm{min}$, Airgas, $99.99 \%)$ for 2 hours at $450{ }^{\circ} \mathrm{C}$, prior to the catalytic test. After reduction, the catalysts were cooled down to the selected reaction temperature under a $\mathrm{H}_{2}$ flow $(10 \mathrm{ml} / \mathrm{min})$. When the temperature was reached, a flow $2.3 \mathrm{mmol} / \mathrm{h}$ of a furfural (Sigma-Aldrich, 99.5\%) solution in cyclopentyl methyl ether (Sigma-Aldrich) (5 vol\%) was continuously injected using a HPLC pump and vaporized into a gas stream of $60 \mathrm{~mL} / \mathrm{min}_{2}$. Cyclopentyl methyl ether is an environmentally friendly solvent that has been used in different organic reactions, thus is a green co-solvent for the selective dehydration of lignocellulosic pentose to furfural. The reaction products were analyzed by gas chromatography (Agilent model 14A) with a flame ionization detector. The product yield and selectivity were defined and calculated as follows:

$$
\begin{aligned}
& \text { Conversion }(\%)=\frac{\text { mol of furfural converted }}{\text { mol of furfural fed }} \times 100 \\
& \text { Selectivity }(\%)=\frac{\text { mol of product produced }}{\text { mol of furfural converted }} \times 100
\end{aligned}
$$

\section{Results and Discussion}

\subsection{Characterization of the Nickel Catalysts}

The Ni content of the synthesized SBA-xNi catalysts, as determined by AAS, was 5.3 and $20.13 \mathrm{wt} \%$. These values and those of other physical properties of the support and the catalysts are displayed in Table 1.

The $\mathrm{N}_{2}$ adsorption-desorption isotherms for SBA-15 and for the calcined SBA-xNi samples are shown in Figure 1. All of them are type-IV isotherms, according to the IUPAC classification, with an H1 hysteresis loop. It can be seen that the shape of the isotherm of pure SBA-15 was preserved even for the catalyst with the highest nickel content, which means that, after impregnation and subsequent calcination of the nickel catalyst precursors, the mesoporous nature of the solid support was maintained. The evaluation of the textural properties of the calcined samples by the analysis of the nitrogen adsorption-desorption isotherms at 77 $\mathrm{K}$ reveals that the BET surface area decreases progressively with the loading of nickel, with a drastic reduction for the material with the highest Ni content (SBA-20Ni) (Table 1). However, the average pore diameter barely changed in comparison with that of the mesoporous silica used as support, thus pointing out to the presence of nickel oxide particles blocking partially the entrance to the mesoporous framework.

Table 1. Physical properties of the support and the catalysts.

\begin{tabular}{ccccc}
\hline Catalyst & Ni content $(\mathrm{wt} \%)$ & $\mathrm{S}_{\mathrm{BET}}\left(\mathrm{m}^{2} / \mathrm{g}\right)$ & $\mathrm{d}_{\mathrm{p}}(\mathrm{nm})$ & $\mathrm{V}_{\mathrm{p}}\left(\mathrm{cm}^{3} / \mathrm{g}\right)$ \\
\hline SBA-15 & - & 580.64 & 3.28 & 0.46 \\
SBA-5Ni & 5.30 & 390.29 & 3.44 & 0.27 \\
SBA-20Ni & 20.13 & 272.74 & 3.45 & 0.21 \\
\hline
\end{tabular}




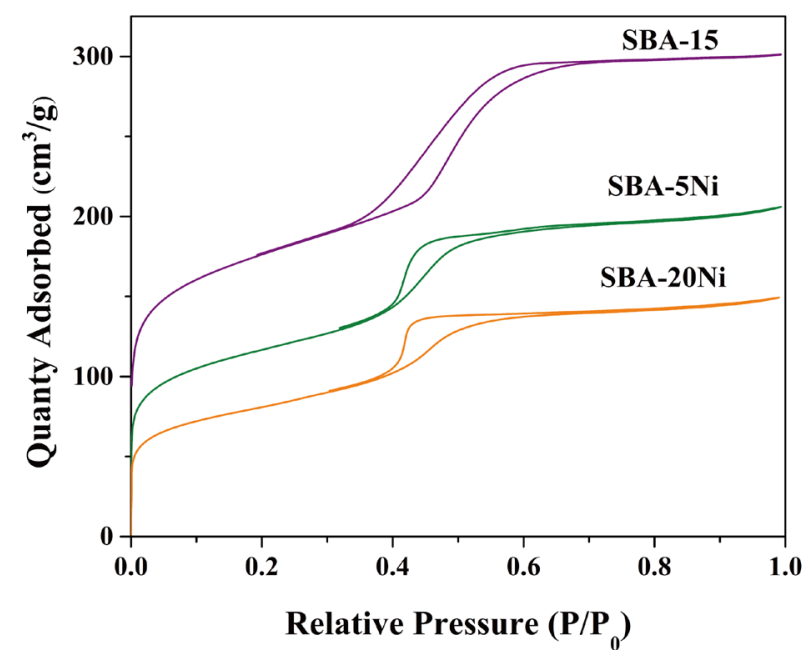

Figure 1. $\mathrm{N}_{2}$ adsorption-desorption isotherms of SBA-15 and of the catalysts.

The crystal structures of the fresh and the used catalysts reduced under $\mathrm{H}_{2}$ at $450^{\circ} \mathrm{C}$ for $1 \mathrm{~h}$ were determined using small-angleXRD (SAXS); the results are shown in Figure 2. SAXS patterns of the catalyst supported on SBA-15 shows a strong $\left(\begin{array}{lll}1 & 0 & 0\end{array}\right)$ reflection $\left(2 \theta=0.90^{\circ}\right)$. Three well-resolved peaks in the $2 \theta=0.90^{\circ}$ region and two small peaks around $2^{\circ}-3^{\circ}$ are observed. These, which are assigned as the $\left(\begin{array}{lll}1 & 0 & 0\end{array}\right),\left(\begin{array}{lll}1 & 1 & 0\end{array}\right)$, and $\left(\begin{array}{lll}2 & 0 & 0\end{array}\right)$ reflections of a 2D hexagonal structure of SBA-15, P6mm, phase, confirming that the mesoporous structure is preserved after nickel incorporation and after the catalytic reaction, the catalysts show the presence of the same peaks.

In the wide-angle XRD patterns of the catalysts reduced under $\mathrm{H}_{2}$ at $450^{\circ} \mathrm{C}$ for $1 \mathrm{~h}$ (Figure 3) there was a wide peak between $2 \theta=20^{\circ}$ and $30^{\circ}$ attributed to the peak of siliceous material. In agreement with previous observations [15] [19], the $\mathrm{Ni}(111)$ and $\mathrm{Ni}(200)$ peaks of monometallic nickel $\left(\mathrm{Ni}^{0}\right)$ were observed at $2 \theta=44.41^{\circ}$ and $51.76^{\circ}$, respectively. However, the XRD patterns of the two samples, when examined at small angle, showed the characteristic peaks of $\mathrm{NiO}$ at $2 \theta=37^{\circ}, 43.1^{\circ}$, and $62.7^{\circ}$, corresponding to the planes (111), (200), and (220) of cubic NiO species [20], respectively. The reduced SBA-5Ni and SBA-20Ni catalysts did show peaks for $\mathrm{NiO}$, indicating that this samples were not completely reduced. The intensity of these reflections increases with increasing amount of nickel deposited. After the catalytic reaction, the catalysts show the presence of the same peaks (Figure 3(b)).

The reduction behavior of $\mathrm{NiO}$ and the interactions between $\mathrm{NiO}$ particles and the supports were investigated using $\mathrm{H}_{2}$-TPR; the results are shown in Figure 4. The SBA-5Ni catalyst showed a reduction peak at low temperature between $281^{\circ} \mathrm{C}$ and $289^{\circ} \mathrm{C}$, but the reduction peaks at high temperature were found over a very wide range of temperature. The reduction peaks in the low temperature region can be attributed to the reduction of $\mathrm{NiO}$ species that have weak interaction with the support, while the reduction peaks in the high temperature region can be attributed to the reduction of fixed $\mathrm{NiO}$ species which have a stronger interaction with the support. As it is observed from Figure 4, at high temperatures there were big differences among the reduction peaks. Thus, SBA-20Ni shows three peaks: the first results from an endothermic phase transition occurring simultaneously with a partial reduction of $\mathrm{NiO}$; the second, which is the main peak, is attributed to the reduction of $\mathrm{NiO}$ to Ni metal [7] [15] [21]; the third could be due to the reduction of small nickel oxide crystallites strongly attached to the support, even forming Ni silicate species (nickel hydroxysilicates, antigorite, or montmorillonite) [22] [23].

The characteristic binding energy (BE) values of $\mathrm{Ni} 2 p_{3 / 2}$, Si $2 p$, O 1s, and $\mathrm{C} 1 s$ for both catalysts, fresh and used, are presented in Table 2. The Si $2 p$ BE values in all the SBA- $x$ Ni catalysts are very similar, and the average value of $103.5 \mathrm{eV}$ is typical of silica. The $\mathrm{O} 1 \mathrm{~s}$ signal is symmetrical and appears at $533 \mathrm{eV}$ in the catalysts; these $\mathrm{BE}$ values for $\mathrm{O} 1 \mathrm{~s}$ are characteristic of silica and metal oxide, respectively. The $\mathrm{Ni} 2 p_{3 / 2}$ signal at $854.8-855.5 \mathrm{eV}$ and $856.4-857.2 \mathrm{eV}$ reveal the existence of $\mathrm{NiO}$ with different degrees of interaction with the support (Table 2). Some spectral signals at $852.4-853.2 \mathrm{eV}$ were observed, which are assigned to $\mathrm{Ni}^{0}$ species. These binding energies are in good agreement with the $\mathrm{Ni} 2 p_{3 / 2}$ values reported in un- 


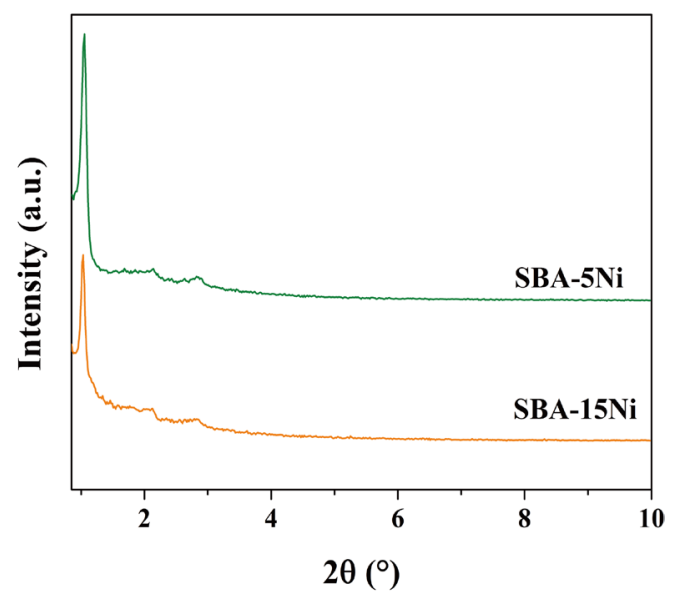

(a)

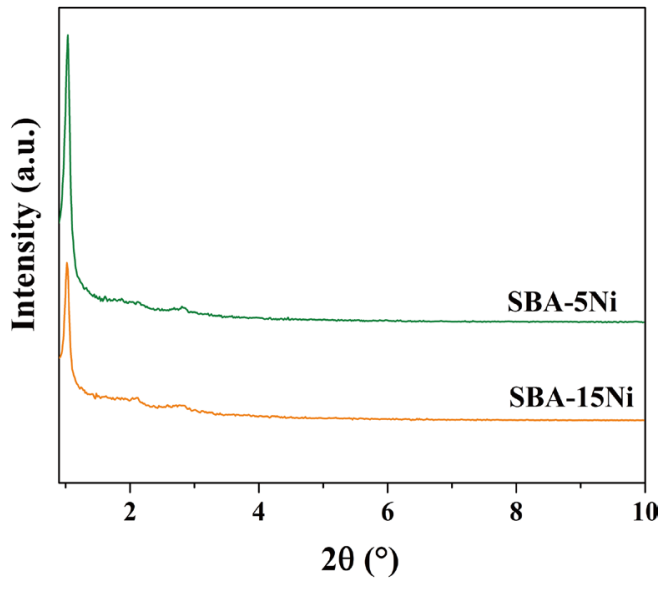

(b)

Figure 2. Small-angle XRD patterns of fresh (a) and used (b) catalysts.

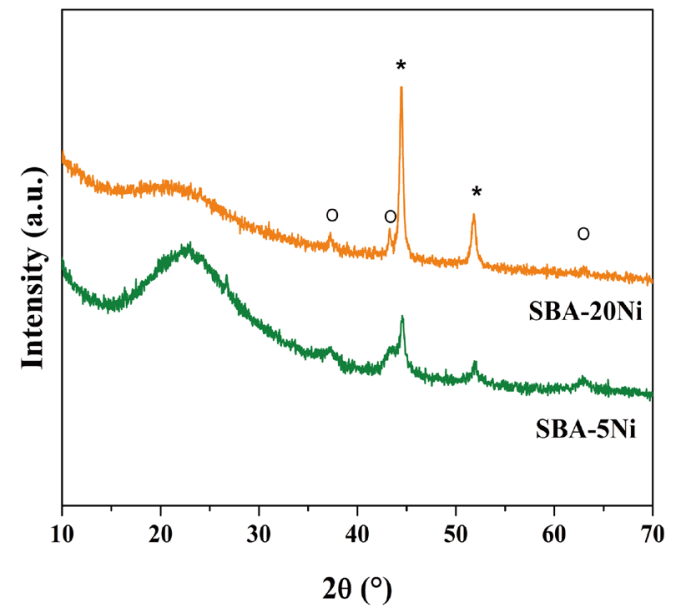

(a)

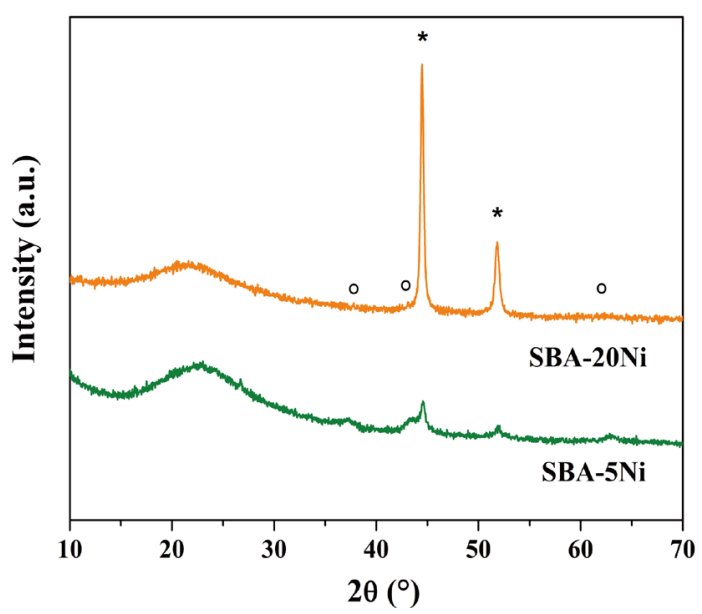

(b)

Figure 3. XRD patterns for fresh (a) and used (b) catalysts. The symbols $*$ and ${ }^{\circ}$ denote the species $\mathrm{Ni}^{0}$ and $\mathrm{NiO}$, respectively.

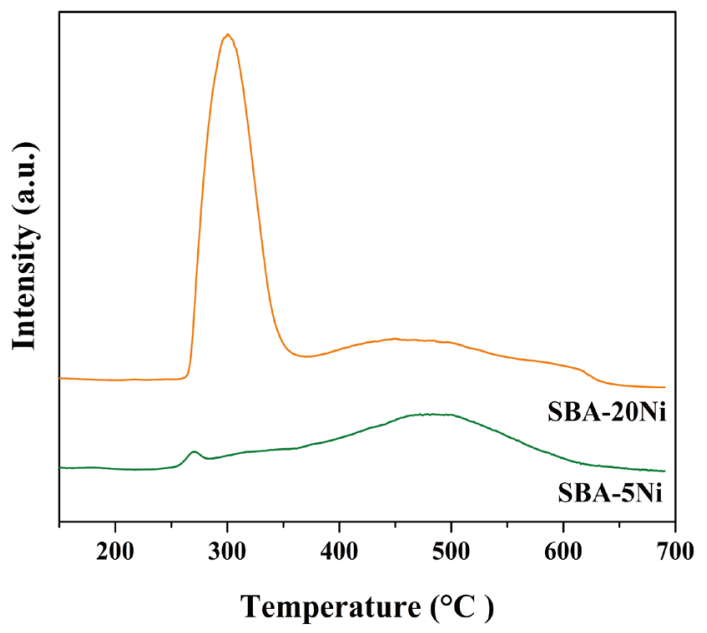

Figure 4. Temperature programmed reduction profiles of the catalysts. 
Table 2. Binding energies (eV) for the catalysts fresh and used.

\begin{tabular}{ccccc}
\hline Catalyst & C $1 s$ & O $1 s$ & Si $2 p$ & Ni $2 p_{3 / 2}$ \\
\hline SBA-5Ni & $284.56(79.6 \%)$ & $530.19(4.10 \%)$ & $102.65(20.0 \%)$ & $853.44(49.9 \%)$ \\
fresh & $285.93(20.4 \%)$ & $532.71(95.90 \%)$ & $103.67(79.7 \%)$ & $856.20(50.1 \%)$ \\
SBA-5Ni & $284.42(80.3 \%)$ & $532.70(100 \%)$ & $103.27(100 \%)$ & $855.07(48.8 \%)$ \\
used & $285.79(19.7 \%)$ & & & $856.93(26.2 \%)$ \\
& & & & $860.84(25.1 \%)$ \\
SBA-20Ni & $284.56(86.9 \%)$ & $530.34(19.9 \%)$ & $102.25(24.1 \%)$ & $852.73(41.7 \%)$ \\
fresh & $285.75(13.1 \%)$ & $532.33(80.1 \%)$ & $103.30(75.9 \%)$ & $855.57(58.3 \%)$ \\
SBA-20Ni & $284.85(84.8 \%)$ & $529.93(11.1 \%)$ & $102.39(32.6 \%)$ & $852.46(41.3 \%)$ \\
used & $287.45(15.2 \%)$ & $532.24(88.9 \%)$ & $103.41(67.4 \%)$ & $855.71(58.7 \%)$ \\
\hline
\end{tabular}

supported Ni 2p $3 / 2$ (857.1 eV) [24] [25].

The morphology and size of the $\mathrm{Ni}^{0}$ particles in the fresh catalysts was studied using TEM; the results are shown in Figure 5. In the TEM images of all the catalysts, the ordered mesoporous structure of SBA-15 can be observed, which is consistent with the results small angle XRD patterns (Figure 2). In addition, $\mathrm{Ni}^{0}$ particles with diameters of about $7 \mathrm{~nm}$ and narrow distributions could be observed. Few clear changes in the pore structure of the catalysts and in the size and distribution of the nickel particles can be observed when comparing the TEM image of a fresh catalyst and the corresponding image of the used catalyst. Furthermore, we can conclude that the transformation of nickel phyllosilicate or nickel hydroxide or the mixtures of them to metallic oxides and metallic nickel arose due to the calcination and the reduction processes, according to the results of XRD patterns (Figure 3) and TEM images (Figure 5).

\subsection{Catalytic Activity Studies}

The two catalysts have been tested in the vapor-phase hydrogenation of furfural at atmospheric pressure. The results of the catalytic activity as a function of time on stream (TOS) at $170^{\circ} \mathrm{C}$ reveal a regular deactivation (Figure 6), which is pronounced in the case of SBA-20Ni. The deactivation process could be explained by the active nickel site coverage by coke or adsorbed reactants/products, as revealed the high carbon percentages found in the spent catalysts by CHN analysis (Table 3), rather than the nickel particle sintering. The carbon deposition is the lowest for the SBA-5Nimaterial, which is that with the highest conversion. In a recent study, the vapor-phase conversion of furfural over $\mathrm{SiO}_{2}$ supported Ni catalysts in the presence of $\mathrm{H}_{2}$ (1 bar) demonstrated a significant deviation in activity [15].

The product distribution obtained by conversion of furfural over the SBA- $x \mathrm{Ni}$ catalysts at $170^{\circ} \mathrm{C}$ is shown in Figure 7. The most abundant products for conversion at this temperature are furfuryl alcohol (FOL selectivity $=$ $34.6 \%$ at $5 \mathrm{~h}^{-1}$ ) and furan (F selectivity $=35 \%$ at $5 \mathrm{~h}^{-1}$ ), which, as shown in Scheme 1, derive from the hydrogenation and decarbonylation reactions, respectively. The next abundant products are those lumped together as $\mathrm{C} 4$ products (selectivity $=23.35 \%$ at $5 \mathrm{~h}^{-1}$ ), which include butanal, butanol, and butane. The $\mathrm{C} 4$ products derive from the ring-opening reaction via $\mathrm{C}-\mathrm{O}$ hydrogenolysis of the furan ring, a typical reaction characteristic of $\mathrm{Ni}$ catalysts [4] [7] [15]. Finally, the least abundant product is 2-methylfuran (MF selectivity $=7.21 \%$ at $0.1 \mathrm{~h}^{-1}$ ), a secondary product resulting from the C-O hydrogenolysis of FOL. These results agree with those of Sitthisa et al. [15] about monometallic Ni catalyst favoring the formation of furfuryl alcohol and furan as primary products via hydrogention and decarbonylation.

Furfuryl alcohol and furan are primary products typically obtained by convertion over Ni-based catalysts [7] [26], and they can further convert to 2-methylfuran and open-ring C4 products, respectively. Our results show that over monometallic Ni catalyst, decarbonylation is favored over hydrogenation. Spectroscopic results and DFT calculations show that, on group VIII metals, aldehydes tend to adsorb with the carbonyl group parallel to the surface $\left(\eta^{2}(\mathrm{C}, \mathrm{O})\right.$-aldehyde) [27]-[30]. This favors the hydrogenation of the carbonyl group, yielding furfuryl alcohol, as experimentally observed at low temperature. However, at high temperature, $\eta^{2}(\mathrm{C}, \mathrm{O})$-furfural tends to 


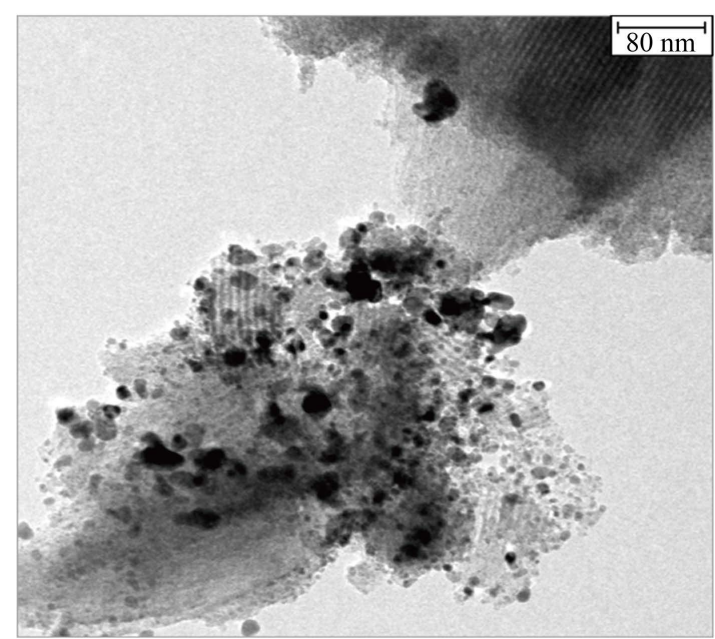

(a)

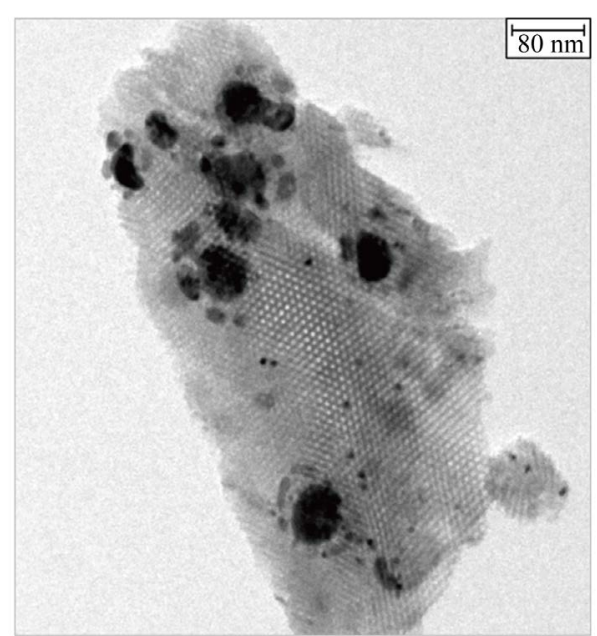

(b)

Figure 5. TEM micrographs of the SBA-5Ni (a) and SBA-20Ni (b) fresh catalysts.

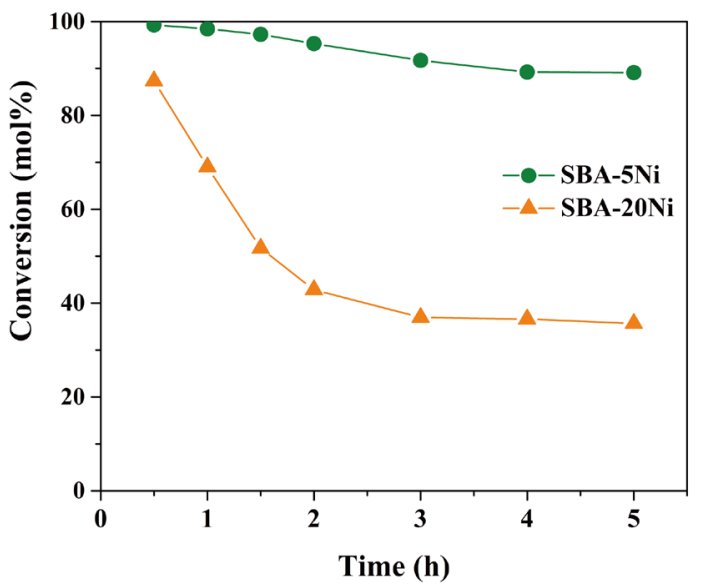

Figure 6. Conversion of furfural over nickel catalysts, at $170^{\circ} \mathrm{C}$, as a function of time on stream. Reaction conditions: $\mathrm{m}_{\text {cat }}=150 \mathrm{mg}, \mathrm{H}_{2}$ flow $=10 \mathrm{~mL} / \mathrm{min}$, feed flow $=2.3 \mathrm{mmol} / \mathrm{h}$.
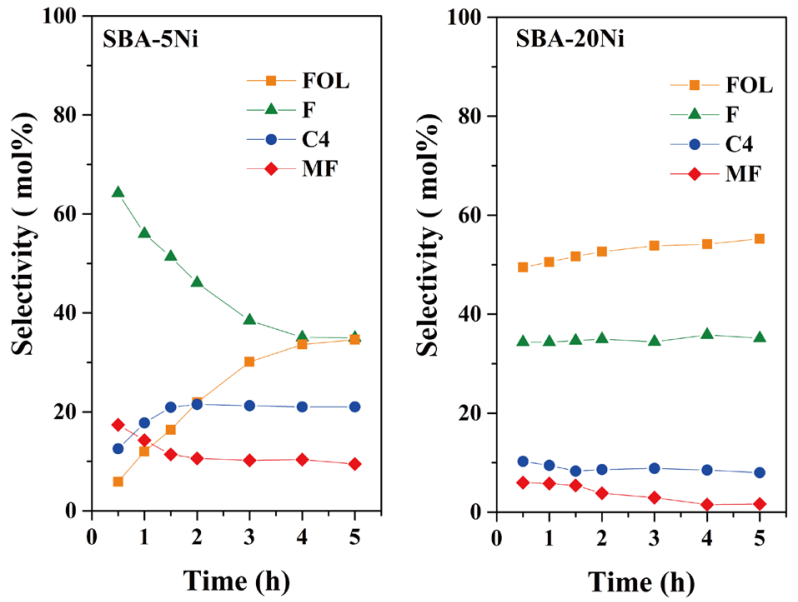

Figure 7. Selectivity for furfuryl alcohol (FOL), furan (F), 2-methylfuran (MF), and C4 (open-ring products) of the catalysts, at $170^{\circ} \mathrm{C}$, as a function of time on stream. Reaction conditions: $\mathrm{m}_{\text {cat }}=150 \mathrm{mg}, \mathrm{H}_{2}$ flow $=10$ $\mathrm{mL} / \mathrm{min}$, feed flow $=2.3 \mathrm{mmol} / \mathrm{h}$. 
Table 3. Chemical analyses of spent catalysts.

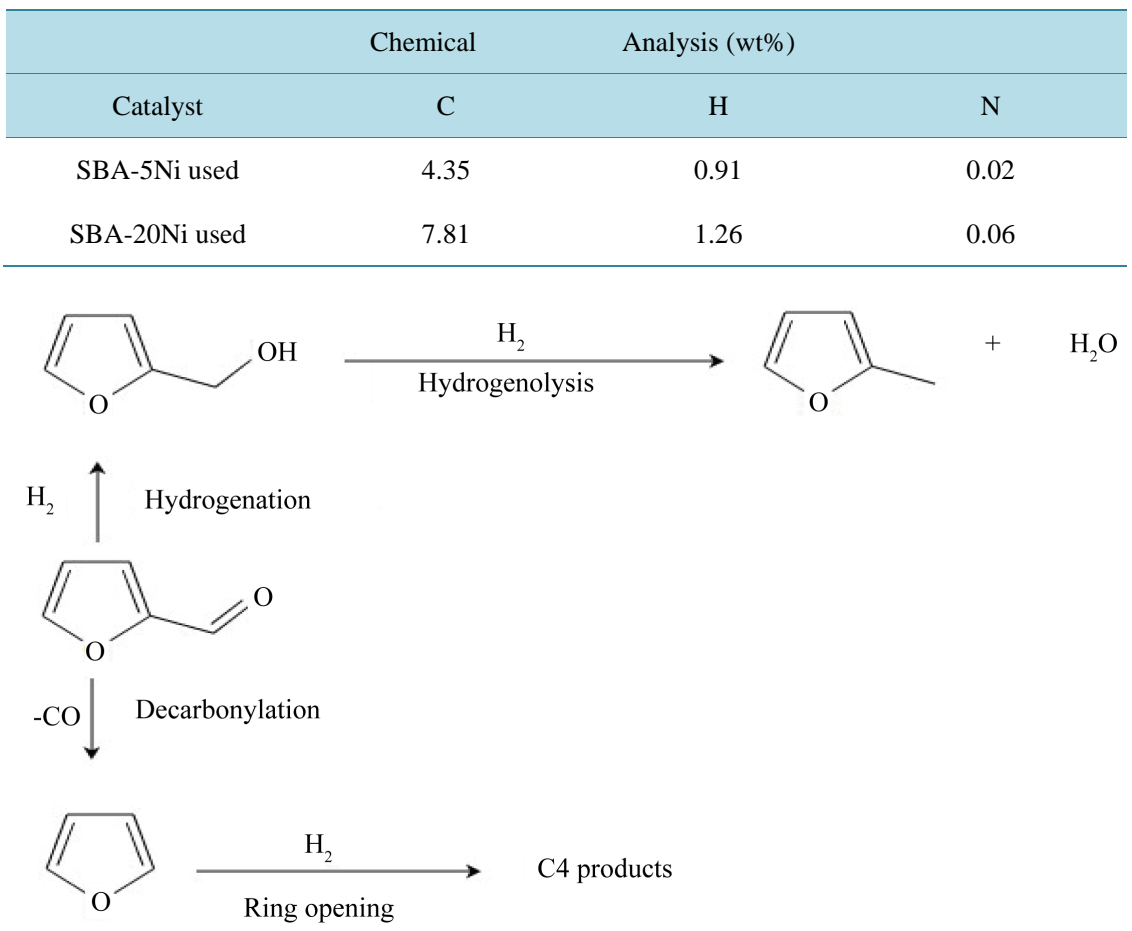

Scheme 1. Reaction pathways for furfural conversion.

decompose into a more stable acyl species, in which the $\mathrm{C}$ atom of the carbonyl remains strongly attached to the surface. This acyl species may in fact be a precursor for the decarbonylation reaction, yielding furan and CO [7].

In addition to the differences in interaction with the carbonyl group itself, different metals have a different extent of interaction with the furanyl ring. For example, while $\mathrm{Cu}$ exerts a repulsion on the ring [7], Group VIII metals tend to interact strongly with aromatic and furanyl rings, as well as with $\mathrm{C}=\mathrm{C}$ double bonds. In particular, on a surface of $\mathrm{Ni}$ the furanyl ring/metal interaction is so strong that the $\mathrm{C}-\mathrm{O}$ bond in the ring weakens and this leads to a significant extent of ring opening, a reaction that is also favored as temperature increases.

The selectivity to 2-methylfuran is an interesting case. Since, as shown above, the C1-O1 hydrogenolysis occurs mainly after furfural has been hydrogenated to furfuryl alcohol and this product is not favored on pure Ni, particularly at the high temperatures required for C-O hydrogenolysis, very small amounts of 2-methylfuran are produced on monometallic Ni [15].

On the other hand, to study the influence of the reaction temperature, results for the conversion of furfural over SBA-5Ni at $230^{\circ} \mathrm{C}$ and the product distribution are shown in Figure 8. It may be seen that for this higher temperature there is a clear increase in conversion, while the production of furan increases in detriment of the production of furfuryl alcohol. Sitthisa et al. [7] have reported the same behavior for $\mathrm{Ni} / \mathrm{SiO}_{2}$. At high temperature, $\eta^{2}(\mathrm{C}, \mathrm{O})$-furfural tends to decompose into a more stable acyl species, in which the $\mathrm{C}$ atom of the carbonyl remains strongly attached to the surface. This acyl species may in fact be a precursor for the decarbonylation reaction, yielding furan and $\mathrm{CO}$. Therefore, the highest temperature, $230^{\circ} \mathrm{C}$, was chosen to optimize other reaction parameters.

\section{Conclusion}

Vapor phase furfural hydrogenation studies were performed on a series of silica supported monodisperse Ni catalysts. It was found that product selectivity was highly dependent on the loading of the catalysts. SBA-5Ni was found to give predominantly furan as a product at $230^{\circ} \mathrm{C}$, via decarbonylation due to the favorable formation of acyl species, which could readily decompose into furan and CO, while SBA-20Ni yielded both furan and furfuryl alcohol, a result of furfural decarbonylation and hydrogenation reactions, respectively. 


\section{Acknowledgements}

This work was financially supported by the Spanish Ministry of Economy and Competitiveness (CTQ-201238204-C03-02), FEDER funds, and the Junta de Andalucía (P09-FQM-5070). One of the authors (RMT) is grateful for financial support received under the Program Ramón y Cajal (RYC-2008-03387) and from the Consejo Nacional de Ciencia y Tecnología (Mexico), via scholarships (219821).

\section{References}

[1] Zeitsch, K.J. (2000) The Chemistry and Technology of Furfural and Its Many By-Products. Elsevier, Amsterdam, Oxford, 13.

[2] Kim, Y.C. and Lee, H.S. (2001) Selective Synthesis of Furfural from Xylose with Supercritical Carbon Dioxide and Solid Acid Catalyst. Journal of Industrial and Engineering Chemistry, 7, 424-429.

[3] Lange, J.P., Van der Heide, E., Van Buijtenen, J. and Price, R. (2012) Furfural-A Promising Platform for Lignocellulosic Biofuels. ChemSusChem, 5, 150-166. http://dx.doi.org/10.1002/cssc.201100648

[4] Xinghua, Z., Tiejun, W., Longlong, M. and Chuangzhi, W. (2010) Aqueous-Phase Catalytic Process for Production of Pentane from Furfural over Nickel-Based Catalysts. Fuel, 89, 2697-2702. http://dx.doi.org/10.1016/j.fuel.2010.05.043

[5] Koso, S., Nakagawa, Y. and Tomishige, K. (2011) Mechanism of the Hydrogenolysis of Ethers over Silica-Supported Rhodium Catalyst Modified with Rhenium Oxide. Journal of Catalysis, 280, 221-229. http://dx.doi.org/10.1016/j.jcat.2011.03.018

[6] Sitthisa, S., Sooknoi, T., Ma, Y., Balbuena, P.B. and Resasco, D.E. (2011) Kinetics and Mechanism of Hydrogenation of Furfural on $\mathrm{Cu} / \mathrm{SiO}_{2}$ Catalysts. Journal of Catalysis, 277, 1-13. http://dx.doi.org/10.1016/j.jcat.2010.10.005

[7] Sitthisa, S. and Resasco, D. (2011) Hydrodeoxygenation of Furfural Over Supported Metal Catalysts: A Comparative Study of Cu, Pd and Ni. Catalysis Letters, 141, 784-791. http://dx.doi.org/10.1007/s10562-011-0581-7

[8] Nagaraja, B.M., Siva Kumar, V., Shasikala, V., Padmasri, A.H., Sreedhar, B., Raju, D.B. and Rama Rao, K.S. (2003) A Highly Efficient $\mathrm{Cu} / \mathrm{MgO}$ Catalyst for vapour Phase Hydrogenation of Furfural to Furfuryl Alcohol. Catalysis Communications, 4, 287-293. http://dx.doi.org/10.1016/S1566-7367(03)00060-8

[9] Rao, R.S., Baker, R.T.K. and Vannice, M.A. (1999) Furfural Hydrogenation over Carbon-Supported Copper. Catalysis Letters, 60, 51-57. http://dx.doi.org/10.1023/A:1019090520407

[10] Vargas-Hernández, D., Rubio-Caballero, J.M, Santamaría-González, J., Moreno-Tost, R., Mérida-Robles, J.M., PérezCruz, M.A., Jiménez-López, A., Hernández-Huesca, R. and Maireles-Torres P. (2014) Furfuryl Alcohol from Furfural Hydrogenation over Copper Supported on SBA-15 Silica Catalysts. Journal of Molecular Catalysis A: Chemical, 383-384,106-113. http://dx.doi.org/10.1016/j.molcata.2013.11.034

[11] Sitthisa, S., Pham, T., Prasomsri, T., Sooknoi, T., Mallinson, R.G. and Resasco, D.E. (2011) Conversion of Furfural and 2-Methylpentanal on $\mathrm{Pd} / \mathrm{SiO}_{2}$ and $\mathrm{Pd}-\mathrm{Cu} / \mathrm{SiO}_{2}$ Catalysts. Journal of Catalysis, 280, 17-27.

http://dx.doi.org/10.1016/j.jcat.2011.02.006

[12] Zhang, W., Zhu, Y., Niu, S. and Li, Y. (2011) A Study of Furfural Decarbonylation on K-Doped Pd/Al $\mathrm{O}_{3} \mathrm{Catalysts.}$ Journal of Molecular Catalysis A: Chemical, 335, 71-81. http://dx.doi.org/10.1016/j.molcata.2010.11.016

[13] Lejemble, P., Gaset, A. and Kalck, P. (1984) From Biomass to Furan Through Decarbonylation of Furfural under Mild Conditions. Biomass, 4, 263-274. http://dx.doi.org/10.1016/0144-4565(84)90039-8

[14] Jung, K.J., Gaset, A. and Molinier, J. (1988) Furfural Decarbonylation Catalyzed by Charcoal Supported Palladium: Part II-A Continuous Process. Biomass, 16, 89-96. http://dx.doi.org/10.1016/0144-4565(88)90018-2

[15] Sitthisa, S., An, W. and Resasco, D.E. (2011) Selective Conversion of Furfural to Methylfuran over Silica-Supported NiFe Bimetallic Catalysts. Journal of Catalysis, 284, 90-101. http://dx.doi.org/10.1016/j.jcat.2011.09.005

[16] Kijeński, J., Winiarek, P., Paryjczak, T., Lewicki, A. and Mikołajska, A. (2002) Platinum Deposited on Monolayer Supports in Selective Hydrogenation of Furfural to Furfuryl Alcohol. Applied Catalysis A: General, 233, 171-182. http://dx.doi.org/10.1016/S0926-860X(02)00140-0

[17] Zhao, D.Y., Feng, J.L., Huo Q.S., Melosh, N., Fredrickson, G.H., Chmelka, B.F and Stucky G.D. (1998) Triblock Copolymer Syntheses of Mesoporous Silica with Periodic 50 to 300 Angstrom Pores. Science, 279, 548-552. http://dx.doi.org/10.1126/science.279.5350.548

[18] Barrett, E., Joyner, L. and Halenda, P. (1951) The Determination of Pore Volume and Area Distributions in Porous Substances. I. Computations from Nitrogen Isotherms. Journal of the American Chemical Society, 73, 373-380. http://dx.doi.org/10.1021/ja01145a126

[19] Wang, L., Zhang, Q., Zhang, J., Sun, S., Guo, H., Jia, Z., Wang, B., Shao, Z., Wang, Z. and Hu, X. (2011) PI3K Path- 
way Activation Results in Low Efficacy of both Trastuzumab and Lapatinib. BMC Cancer, 11, 248. http://dx.doi.org/10.1186/1471-2407-11-248

[20] Habimana, F., Li, X., Ji, S., Lang, B., Sun, D. and Li, C. (2009) Effect of Cu Promoter on Ni-Based SBA-15 Catalysts for Partial Oxidation of Methane to Syngas. Journal of Natural Gas Chemistry, 18, 392-398. http://dx.doi.org/10.1016/S1003-9953(08)60130-9

[21] Ermakova, M.A. and Ermakov, D.Y. (2002) Ni/SiO 2 and $\mathrm{Fe} / \mathrm{SiO}_{2}$ Catalysts for Production of Hydrogen and Filamentous Carbon via Methane Decomposition. Catalysis Today, 77, 225-235. http://dx.doi.org/10.1016/S0920-5861(02)00248-1

[22] Mile, B., Stirling, D., Zammitt, M.A., Lovell, A. and Webb, M. (1990) TPR Studies of the Effects of Preparation Conditions on Supported Nickel Catalysts. Journal of Molecular Catalysis, 62, 179-198. http://dx.doi.org/10.1016/0304-5102(90)85212-Z

[23] Gómez-Reynoso, R., Ramírez, J., Nares, R., Luna, R., and Murrieta, F. (2005) Characterization and Catalytic Activity of Ni/SBA-15, Synthesized by Deposition-Precipitation. Catalysis Today, 107, 926-932. http://dx.doi.org/10.1016/j.cattod.2005.07.152

[24] Korányi, T.I. (2003) Phosphorus promotion of Ni (Co)-containing Mo-Free Catalysts in Thiophene Hydrodesulfurization. Applied Catalysis A: General, 239, 253-267. http://dx.doi.org/10.1016/S0926-860X(02)00390-3

[25] Korányi, T.I., Vít, Z., Poduval, D.G., Ryoo, R., Kim, H.S. and Hensen, E.J.M. (2008) SBA-15-Supported Nickel Phosphide Hydrotreating Catalysts. Journal of Catalysis, 253, 119-131. http://dx.doi.org/10.1016/j.jcat.2007.10.012

[26] Lukes, R.M. and Wilson, C.L. (1951) Reactions of Furan Compounds. XI. Side Chain Reactions of Furfural and Furfuryl Alcohol over Nickel-Copper and Iron-Copper Catalysts. Journal of the American Chemical Society, 73, 47904794. http://dx.doi.org/10.1021/ja01154a093

[27] Shekhar, R., Barteau, M.A., Plank, R.V. and Vohs, J.M. (1997) Adsorption and Reaction of Aldehydes on Pd Surfaces. The Journal of Physical Chemistry B, 101, 7939-7951. http://dx.doi.org/10.1021/jp9710771

[28] Davis, J.L. and Barteau, M.A. (1989) Polymerization and Decarbonylation Reactions of Aldehydes on the Pd(111) Surface. Journal of the American Chemical Society, 111, 1782-1792. http://dx.doi.org/10.1021/ja00187a035

[29] Lee, S.P. and Chen, Y.W. (1999) Selective Hydrogenation of Furfural on Ni-P, Ni-B, and Ni-PB Ultrafine Materials. Industrial and Engineering Chemistry Research, 38, 2548-2556. http://dx.doi.org/10.1021/ie990071a

[30] Li, H., Zhang, S. and Luo, H. (2004) A Ce-Promoted Ni-B Amorphous Alloy Catalyst (Ni-Ce-B) for Liquid-Phase Furfural Hydrogenation to Furfural Alcohol. Materials Letters, 58, 2741-2746. http://dx.doi.org/10.1016/j.matlet.2004.04.003

\section{Submit or recommend next manuscript to SCIRP and we will provide best service for you:}

Accepting pre-submission inquiries through Email, Facebook, LinkedIn, Twitter, etc. A wide selection of journals (inclusive of 9 subjects, more than 200 journals)

Providing 24-hour high-quality service

User-friendly online submission system

Fair and swift peer-review system

Efficient typesetting and proofreading procedure

Display of the result of downloads and visits, as well as the number of cited articles

Maximum dissemination of your research work

Submit your manuscript at: http://papersubmission.scirp.org/ 